\title{
Response to gonadotropin-releasing hormone challenge: Seasonal variation in steroid production in a viviparous lizard, Tiliqua nigrolutea
}

\author{
Ashley Edwards*, Susan M. Jones \\ School of Biological Sciences, University of Tasmania, Private Bag 55, Hobart, Tasmania 7001, Australia
}

\section{A R T I C L E I N F O}

\section{Article history:}

Received 23 April 2015

Revised 30 October 2015

Accepted 2 November 2015

Available online 10 November 2015

\section{Keywords:}

Estrogen

Hypothalamic-Pituitary-Gonadal axis

Reptile

Seasonal reproduction

Testosterone

\begin{abstract}
A B S T R A C T
The hypothalamic-pituitary-gonadal axis plays a central role in the regulation of gamete maturation, sex steroid production and the stimulation of reproductive behaviours in vertebrates. In seasonal breeders, the timely activation and deactivation of this control system is important to ensure successful reproduction: this process is not well understood in species which breed irregularly. Males of the viviparous blotched blue-tongued lizard, Tiliqua nigrolutea, breed annually, while females display a multiennial cycle. We investigated seasonal variation in hypothalamic-pituitary-gonadal axis responsiveness in both sexes of $T$. nigrolutea. We measured changes in plasma concentrations of testosterone and estrogen in response to a single intraperitoneal injection of a GnRH agonist, chicken-II LH-RH, at three reproductively distinct times of year. Plasma testosterone concentrations in males were significantly increased during gonadal quiescence, but not initial or final spermatogenesis. There was no estrogen response in males at any time of year. Conversely, in females, there was an increase in plasma testosterone, but not estrogen, concentration, in reproductively quiescent females several months in advance of a successful pregnancy. These results indicate clear variation in HPG axis activity with sex, season and reproductive condition in this seasonally breeding viviparous lizard. This study opens the way for further investigation into the mechanisms by which internal (body condition) and external seasonal cues (temperature and photoperiod) are coordinated to regulate reproduction in irregularly-breeding reptiles.
\end{abstract}

(c) 2015 Elsevier Inc. All rights reserved.

\section{Introduction}

The hypothalamic-pituitary-gonadal (HPG) axis is responsible for regulating reproduction in vertebrates (Hseuh and Jones, 1981). Hypothalamic neurohormones, primarily gonadotrophinreleasing hormone $(\mathrm{GnRH})$, regulate production of the pituitary gonadotrophins, luteinising hormone (LH) and folliclestimulating hormone (FSH). These in turn stimulate gamete maturation and the synthesis and release of the primary gonadal steroid hormones, testosterone (T) and oestradiol (E2), which regulate many aspects of vertebrate reproductive physiology and behaviour. Changes in the responsiveness of the HPG axis to external stimuli such as photoperiod or temperature synchronise the timing and frequency of reproduction.

Seasonally breeding, temperate-zone ectotherms such as reptiles are constrained by temperature, to ensure that breeding takes place at an appropriate time of year to optimise offspring survival (Shine and Olsson, 2003). In such species, it is important that the HPG axis is activated, and deactivated, in a timely and appropriate

\footnotetext{
* Corresponding author.

E-mail address: Ashley.Edwards@utas.edu.au (A. Edwards).
}

fashion: most temperate climate reptiles have restricted periods during which reproduction is likely to be successful (Lovern, 2011). In seasonally reproducing species, therefore, activation of the HPG axis is associated with gonadal recrudescence, peak sex steroid concentrations and mating (Jawor et al., 2006).

A gonadotropin-releasing hormone challenge is a wellestablished method of assessing reproductive status by measuring changes in plasma sex steroid concentration in response to a standardised injection of (usually synthetic) GnRH. Such studies have been undertaken in a variety of vertebrate taxa, including mammals (Kriegsfeld and Nelson, 1999), birds (Devries et al., 2011; Jawor et al., 2006) and reptiles (Jones, 2011; Kumar et al., 2011). However, seasonal variation in HPG axis responsiveness in reptiles, particularly in less-than-annual breeders, has not been well studied. In particular, little is known about how HPG axis responsiveness varies in species which require a threshold body condition for successful breeding (Aubret et al., 2002; Bonnet et al., 1994), necessitating adjustment of the timing of HPG axis responsiveness to environmental cues.

The blotched blue-tongued lizard, Tiliqua nigrolutea, is a temperate climate viviparous lizard. Substantial knowledge of this species' reproductive physiology is already available and, being a large 
lizard amenable to being bred in captivity, the species represents an excellent model for studies of reptilian reproductive physiology (Lovern, 2011). Male reptiles typically display an annual pattern of plasma $T$ with low concentrations during the early stages of spermatogenesis and a peak during spermiogenesis, corresponding with peak testicular hypertrophy (Lance, 1984). Male T. nigrolutea follow this pattern (Edwards and Jones, 2001a), displaying a type III reproductive cycle (sensu Heatwole and Taylor, 1987) characterised by Autumn to Spring spermatogenesis and Spring mating. Females of $T$. nigrolutea are live-bearing: they complete a reproductive effort within a single active season, but individual females only breed every 2-4 years (Edwards et al., 2002b). As the multiennial cycle of female breeding is not synchronised between individuals, at any given time there are both reproductively active (vitellogenic, mating, gestating or post parturient) and quiescent (regressed ovaries throughout a given reproductive season) females present in the population. This observation suggests that reproductively mature females of $T$. nigrolutea respond to external stimuli and synchronise reproduction via the HPG axis in breeding years, but in non-breeding years the HPG axis is dissociated from external cues to prevent premature reproductive efforts.

We investigated the ability of the HPG axis to respond to $\mathrm{GnRH}$ by producing sex steroids ( $\mathrm{T}$ and Estrogen (E)) during three physiologically distinct phases of the reproductive cycle, in males, and in both reproductive and quiescent females of $T$. nigrolutea. Both $T$ and E cycle seasonally, peaking coincident with key aspects of reproduction in males (Edwards and Jones, 2001a) and in females (Edwards and Jones, 2001b). We hypothesised that in males, exogenous GnRH would stimulate increased plasma T concentrations in both Spring (final spermatogenesis) and, to a lesser extent, in Autumn (initiation of spermatogenesis), while E would be most readily stimulated in Autumn, as this hormone is known to be important in the early stages of spermatogenesis in other reptiles (Chieffi et al., 2002). In females we expected that there would be clear differences between reproductive and quiescent individuals during Spring (vitellogenesis), and again in Autumn (parturition) with the HPG axis more sensitive to stimulation, assessed by changes in plasma $\mathrm{E}$ concentrations, in reproductive females at these times.

\section{Materials and methods}

\subsection{Husbandry}

Adult T. nigrolutea were sourced from our long-term captive breeding colony held at the University of Tasmania; thus all individuals used in this study had known reproductive histories. Twenty-one adult males and nineteen females were available for study. Animals were housed in mixed-sex cages and fed three times weekly on a varied diet of moist dog food (supplemented weekly with multivitamins and calcium), fresh fruits, vegetables and snails. Water was available ad libitum. Outdoor, semi-natural enclosures meant that animals were subject to natural variations in photoperiod and temperature although supplemental basking lamps were provided. Additional husbandry details are described in Edwards and Jones (2001a,b).

\subsection{Study animals and assignment to experimental groups}

Adult females (snout to vent length (SVL) $\geqslant 26 \mathrm{~cm}$ ), and males $(\mathrm{SVL} \geqslant 24 \mathrm{~cm})$ were sampled in three seasons (Spring, Summer, Autumn) representing key phases of the reproductive cycle (Table 1). As females of this species breed irregularly, they were initially identified as 'reproductive' or 'quiescent' based on their known reproductive history (Edwards et al., 2002b), and manual
Table 1

Reproductive phases throughout $\mathrm{GnRH}$ challenge and blood sampling regime in adult male and female Tiliqua nigrolutea.

\begin{tabular}{clll}
\hline Animal & Spring & Summer & Autumn \\
\hline Males & $\begin{array}{l}\text { Hypertrophied } \\
\text { testes, late } \\
\text { spermatogenesis } \\
\text { (October) }\end{array}$ & $\begin{array}{l}\text { Regressed } \\
\text { testes (January) }\end{array}$ & $\begin{array}{l}\text { Recrudescing } \\
\text { testes, early } \\
\text { spermatogenesis } \\
\text { (March) }\end{array}$ \\
$\begin{array}{c}\text { Reproductive } \\
\text { females }\end{array}$ & $\begin{array}{l}\text { Hypertrophied } \\
\text { ovaries, } \\
\text { vitellogenesis }\end{array}$ & $\begin{array}{l}\text { Regressed } \\
\text { ovaries, } \\
\text { pregnancy } \\
\text { (October) }\end{array}$ & $\begin{array}{l}\text { Regressed ovaries, } \\
\text { post parturition } \\
\text { (March-April) }\end{array}$ \\
& $\begin{array}{l}\text { (Degrember) } \\
\text { females ovaries }\end{array}$ & $\begin{array}{l}\text { Regressed } \\
\text { ovaries } \\
\text { (December) }\end{array}$ & $\begin{array}{l}\text { Regressed ovaries } \\
\text { (March) }\end{array}$ \\
& & & \\
\hline
\end{tabular}

palpation for developing follicles during the vitellogenic period (Gartrell et al., 2002). Reproductive state was confirmed at parturition; females were then allocated definitively to groups for data interpretation.

\subsection{Injections and blood sampling}

Chicken-II GnRH acts effectively in lizard species (Husak et al., 2009; Somoza et al., 2002). Males were randomly allocated to one of four treatment groups: control (isotonic saline), low $\left(1 \mathrm{ng} \mathrm{g}^{-1}\right)$, mid $\left(100 \mathrm{ng} \mathrm{g}^{-1}\right)$, or high $\left(1 \mu \mathrm{g} \mathrm{g}^{-1}\right)$. Females (tentatively assigned to reproductive groups) were randomly allocated to one of three treatment groups (control, low or high). For both males and females, mean SVL did not vary significantly between groups for any sample period (data not presented).

At the start of each sampling period, an initial $\left(t_{0 \mathrm{~h}}\right)$ blood sample $(1.0 \mathrm{ml})$ was collected from the caudal artery by heparinised syringe as previously described (Edwards and Jones, 2001a,b). The animal then immediately received an intra-peritoneal (i.p.) injection of GnRH analogue (Chicken-II LH-RH) (Husak et al., 2009) or isotonic saline, and was returned to its home cage until a second blood sample $(1.0 \mathrm{ml})$ was collected $2 \mathrm{~h}$ later $\left(t_{2 \mathrm{~h}}\right)$. All blood samples were held on ice until centrifugation; plasma was stored frozen at $-20^{\circ} \mathrm{C}$ until later analysis by radioimmunoassay (RIA) of steroid hormones.

\subsection{Hormone assays}

Estrogen was measured in $50 \mu$ l plasma using Spectria coatedtube RIA kits (Orion Diagnostica) that have previously been validated for T. nigrolutea plasma (Edwards and Jones, 2001a,b). Estrogen, rather than oestradiol specifically, is reported, as Edwards et al. (2002a) describe the possibility of an atypical estrogen in this species that cross-reacts with the oestradiol antibody employed in this assay. Inter- and intra-assay coefficients of variation for the $\mathrm{E}$ assay were $13 \%$ and $8 \%$, respectively. For the T assay, steroids were extracted from $50 \mu \mathrm{l}$ plasma in $0.5 \mathrm{ml}$ ethyl acetate (extraction efficiency $=82 \%$ ). Testosterone antiserum was from Sirosera, scintillation fluid was Ecolite ${ }^{\mathrm{TM}}$ and tritiated testosterone $\left(\left[1,2,6,7-{ }^{3} \mathrm{H}\right]-\mathrm{T}\right.$ was from Amersham. Intra- and interassay coefficients of variation for the testosterone assay were $6 \%$ and $<10 \%$ respectively. The limit of detection for both assays was $10 \mathrm{pg}$ authentic steroid. Further details of the $\mathrm{T}$ and $\mathrm{E}$ assays are available in Edwards and Jones (2001a,b).

\subsection{Statistical analysis}

Plasma steroid data from males were analysed by three way repeated measures (RM) analysis of variance (ANOVA), with season (Spring, Summer or Autumn), sample time $\left(t_{0 \mathrm{~h}}\right.$ or $\left.t_{2 \mathrm{~h}}\right)$ and 
treatment (control, low, mid or high dose) as fixed factors and plasma hormone ( $\mathrm{T}$ or $\mathrm{E}$ ) concentration as the response variable to examine the effect of season on the response to the treatment. All values were log transformed prior to analysis to satisfy the assumptions of normality and homoscedasticity. Additionally, mean percentage change in plasma hormone concentration $\left(\left(\left(t_{2 \mathrm{~h}}-t_{0 \mathrm{~h}}\right) / t_{0 \mathrm{~h}}\right) \times 100\right)$ response to different $\mathrm{GnRH}$ doses in each season was analysed by one way RM ANOVA - these data were not transformed.

Female data were not analysed due to small and varied sample sizes. As already noted, females could only be conclusively assigned to breeding or non-breeding status retrospectively following parturition. All graphed data are means \pm one standard error of the mean (SEM). Sample sizes are indicated in figure legends.

\section{Results}

\subsection{Testosterone in males}

For all seasonal samples, initial $\left(t_{0}\right)$ mean plasma concentrations corresponded with previously published $\mathrm{T}$ concentrations (Edwards and Jones, 2001a) and no control group means differed significantly after $2 \mathrm{~h}$ in response to saline injection. In males, the season (and associated reproductive condition) had a significant effect on their response to GnRH (3 way RM ANOVA: $F_{(2}$, $24)=19.508, P \leqslant 0.0005)$ ). There was no season by treatment interaction effect ( 3 way RM ANOVA: $F_{(6,49)}=1.539, P=0.185$ ).

In Spring (final spermatogenesis), $t_{0 \mathrm{~h}}$ mean circulating plasma $\mathrm{T}$ concentrations did not differ significantly between treatment groups (Fig. 1a) and animals responded to the GnRH by increasing plasma $\mathrm{T}$ concentrations after $2 \mathrm{~h}$. The maximum mean T concentration of $20 \pm 5.9 \mathrm{ng} \mathrm{ml}^{-1}$ occurred in response to the high dose treatment, representing a $118 \%$ increase in plasma testosterone concentrations $2 \mathrm{~h}$ after GnRH administration. This approached a significant difference from the control group (independent $t$ test, $t=-2.305, d f=7, P=0.054)$. The mid dose treatment group also showed an increase in plasma $\mathrm{T}$ approaching significance (paired $t$-test, $t=-2.480, d f=4, P=0.068$ ). Due to high individual variation, overall differences in mean percentage change between each treatment groups only approached significance (1 way ANOVA, $\left.F_{(3,15)}=2.854, P=0.072\right)$.

In Summer (testicular quiescence), $t_{0 \mathrm{~h}}$ circulating plasma $\mathrm{T}$ concentrations were noticeably lower than in Spring and did not differ significantly between treatment groups (Fig. 1b). Mean percentage change compared to initial concentrations between paired samples within each treatment group differed significantly (1 way ANOVA, $\left.F_{(3,17)}=3.361, P=0.043\right)$. Mean summer plasma $t_{2 \mathrm{~h}}$ concentrations were also lower than in Spring; mean $\mathrm{T}$ concentration following the high dose $\mathrm{GnRH}$ injection was $9.3 \pm 1.1 \mathrm{ng} \mathrm{ml}^{-1}$, although this represented a $160 \%$ mean increase at $t_{2 \mathrm{~h}}$ in circulating T concentration. The mid (paired $t$-test, $t=-2.552, d f=4, P=0.063$ ) and high (paired $t$-test, $t=-2.412, d f=5, P=0.061$ ) dose treatment groups showed mean increases nearing significance at $t_{2 \mathrm{~h}}$.

In Autumn (early spermatogenesis), mean circulating $\mathrm{T}$ concentrations in $t_{0}$ samples were intermediate between Spring and Summer values (Fig. 1c). No significant response to any dose of GnRH was observed, and there were no significant differences in mean percentage change in plasma $\mathrm{T}$ concentration from $t_{0 \mathrm{~h}}$ to $t_{2 \mathrm{~h}}$ between paired samples for any treatment group during this phase of the reproductive cycle.

\subsection{Estrogen in males}

For all seasonal samples, initial $\left(t_{0 \mathrm{~h}}\right)$ mean plasma concentrations corresponded with previously published E concentrations a

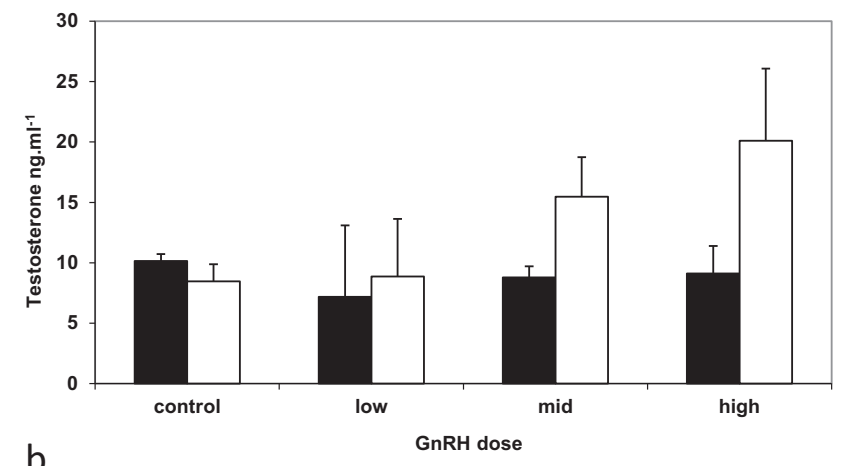

b

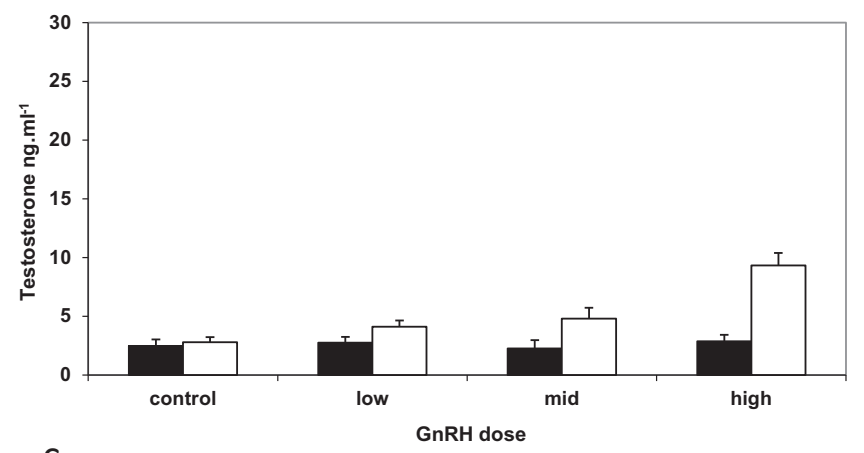

C

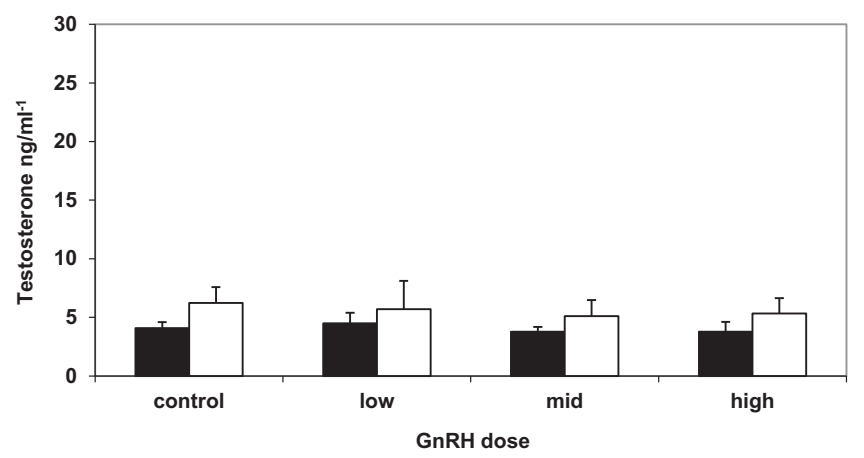

Fig. 1. Plasma testosterone concentrations in male Tiliqua nigrolutea in (a) Spring (b) Summer and (c) Autumn before and after intraperitoneal GnRH injection (control: isotonic saline, low $\left(1 \mathrm{ng} \mathrm{g}^{-1}\right)$, mid $\left(100 \mathrm{ng} \mathrm{g}^{-1}\right)$, or high $\left(1 \mu \mathrm{g} \mathrm{g}^{-1}\right) \mathrm{GnRH}$ ). Sample sizes: Spring (control $n=5$; low $n=5$; mid $n=5$; high $n=4$ ), Summer (control $n=5$; low $n=5$; mid $n=5$; high $n=6$ ) and Autumn (control $n=5$; low $n=5$; mid $n=5$; high $n=6$ ). Values are means \pm 1 SEM.

(Edwards and Jones, 2001b) and no control group means differed significantly after $2 \mathrm{~h}$ in response to saline injection. There was no significant change in mean circulating $\mathrm{E}$ concentrations in response to any GnRH dose in male lizards at any time of year. although there was a great deal of individual variation in both the direction and magnitude of response. However, mean plasma E concentrations at $t_{0 \mathrm{~h}}\left(1109 \pm 193.4 \mathrm{pg} \mathrm{ml}^{-1}\right)$ were significantly elevated ( 1 way ANOVA: $F_{(2,60)}=17.322, P \leqslant 0.0005$ ) during Spring, compared with males sampled during Summer $\left(421 \pm 61.3 \mathrm{pg} \mathrm{ml}^{-1}\right)$ and Autumn $\left(570 \pm 61.0 \mathrm{pg} \mathrm{ml}^{-1}\right)$.

\subsection{Estrogen in females}

Females were allocated retrospectively to a reproductive state for the whole experiment, resulting in uneven sample sizes. For all seasonal samples, initial $\left(t_{0 \mathrm{~h}}\right)$ mean plasma concentrations corresponded with previously published E concentrations (Edwards and Jones, 2001a). Statistical analyses were not conducted due to 
low sample sizes and there were no significant changes in plasma $\mathrm{E}$ concentration in response to GnRH injection between vitellogenic and quiescent females in Spring (Fig. 2a) or Summer (Fig. 2b). However, in Summer there was a qualitative difference in percentage change in plasma E concentration following GnRH injection: pregnant females exhibited a mean decrease in circulating E2, while quiescent females exhibited a mean increase. In Autumn, the previously reproductive females were now post parturient, while the individuals identified as quiescent remained so: percentage change in plasma E concentration in response to GnRH injection varied markedly between individuals and between treatment groups (Fig. 2c).
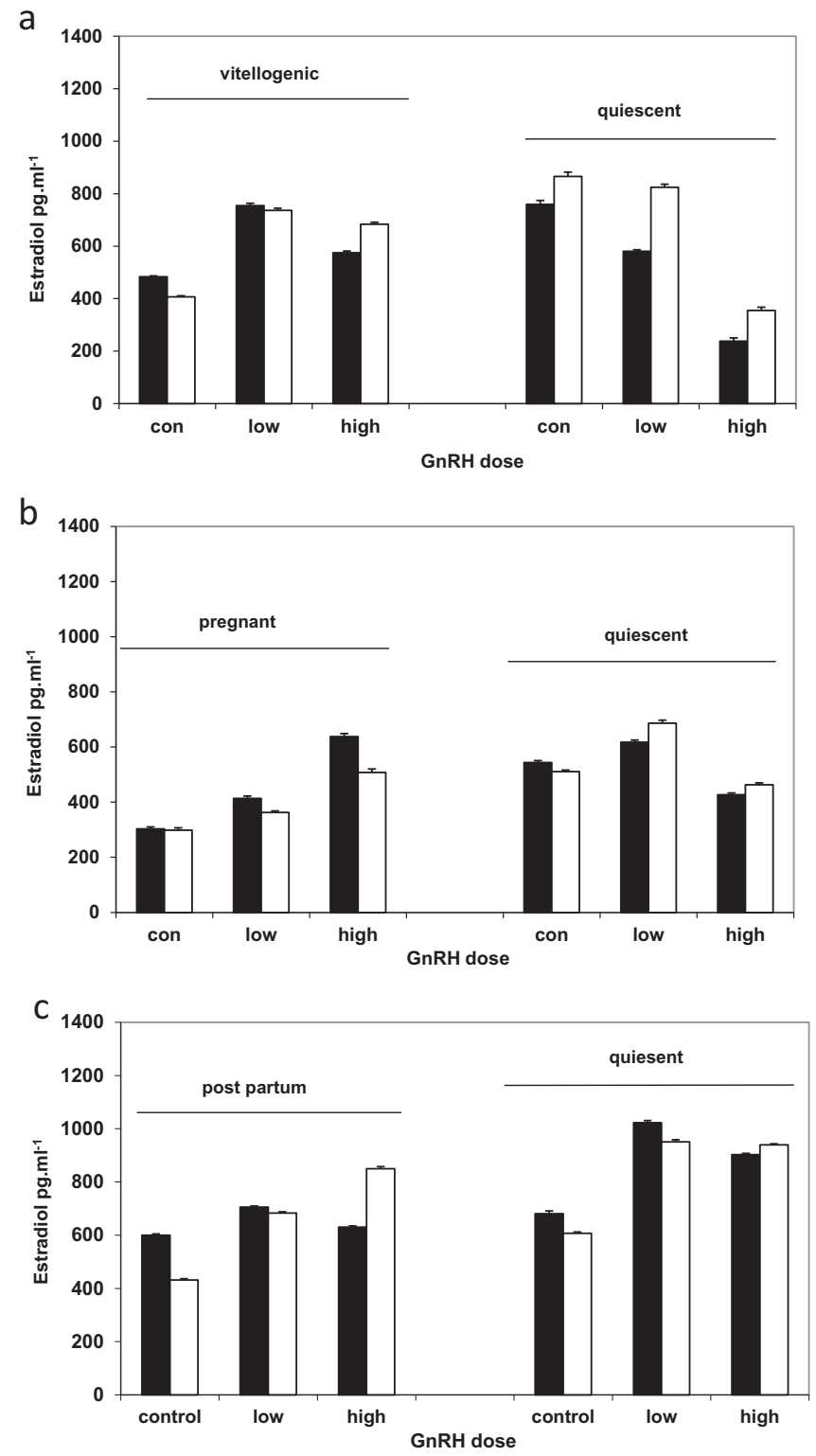

Fig. 2. Percentage change in plasma estrogen concentrations by reproductive and quiescent female Tiliqua nigrolutea in (a) Spring, (b) Summer and (c) Autumn before $\left(t_{0}\right.$, black bars) and after ( $t_{2}$, white bars) intraperitoneal $\mathrm{GnRH}$ injection (control: isotonic saline, low $\left(1 \mathrm{ng} \mathrm{g}^{-1}\right)$, or high $\left.\left(1 \mu \mathrm{g} \mathrm{g}^{-1}\right)\right)$. Sample sizes: Spring (vitellogenic: control $n=3$; low $n=4$; high $n=4$; quiescent control $=2$; low $=3$; high $=2$ ), Summer (pregnant: control $n=3$; low $n=3$; high $n=2$; quiescent: control $n=3$; low $n=2$; high $n=5$ ) and Autumn (postpartum: control $n=3$; low $n=2$; high $n=3$; quiescent: control $n=3$; low $n=2$; high $n=3$ ). Values are means \pm 1 SEM.

\subsection{Testosterone in females}

Sample sizes were small and data were not analysed statistically. For all seasonal samples, initial $\left(t_{0 \mathrm{~h}}\right)$ mean plasma concentrations corresponded with previously published $\mathrm{T}$ concentrations (Edwards and Jones, 2001b). Circulating $t_{0} \mathrm{~T}$ concentrations in Spring were higher in vitellogenic $\left(0.83 \pm 0.45 \mathrm{ng} \mathrm{ml}^{-1}, N=12\right)$ than quiescent $\left(0.36 \pm 0.34 \mathrm{ng} \mathrm{ml}^{-1}, N=7\right)$ females but there were no changes in plasma $\mathrm{T}$ concentration in response to $\mathrm{GnRH}$ injections (Fig. 3a).
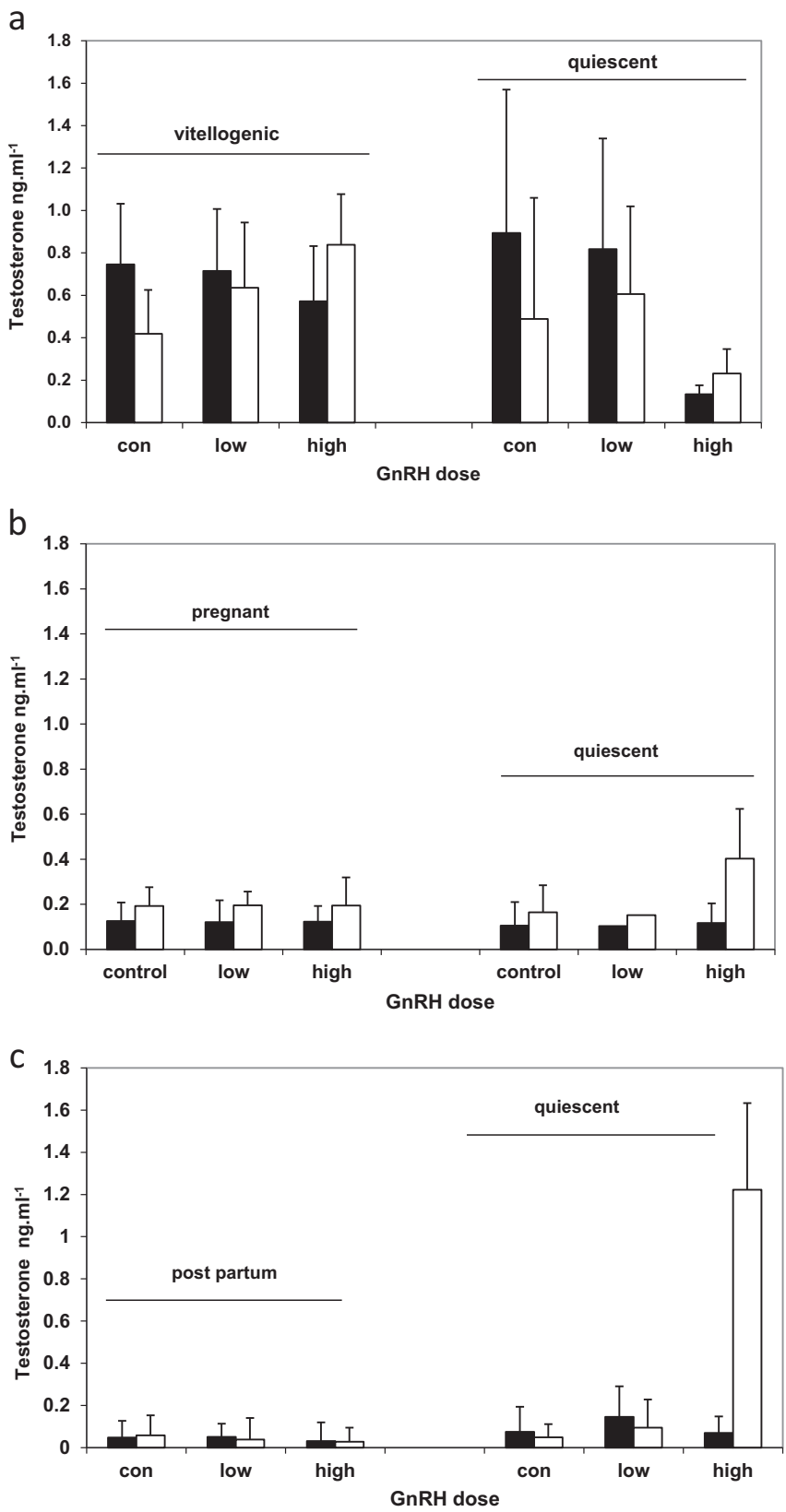

Fig. 3. Percentage change in plasma testosterone concentrations by reproductive and quiescent female Tiliqua nigrolutea in (a) Spring, (b) Summer and (c) Autumn before $\left(t_{0}\right.$, black bars) and after $\left(t_{2}\right.$, white bars) intraperitoneal GnRH injection (control: isotonic saline, low $\left(1 \mathrm{ng} \mathrm{g}^{-1}\right)$, or high $\left(1 \mu \mathrm{g} \mathrm{g}^{-1}\right)$ ). Sample sizes: Spring (vitellogenic control = 3; low $=4$; high $=5 ;$ quiescent control = 2; low = 3; high = 2), Summer (pregnant: control $n=3$; low $n=4$; high $n=4$; quiescent: control $n=2$; low $n=1$; high $n=3$ ) and Autumn (postpartum: control $n=3$; low $n=2$; high $n=3$; quiescent: control $n=3$; low $n=4$; high $n=4$ ). Values are means \pm 1 SEM. 
Mean circulating $t_{0} \mathrm{~T}$ concentration in females in Summer $\left(0.11 \pm 0.01 \mathrm{ng} \mathrm{ml}^{-1}, N=18\right)$ was lower than in Spring and did not differ between pregnant and quiescent animals. The most notable mean increase in circulating plasma $\mathrm{T}$ (239\%) occurred in the quiescent females which received the high GnRH dose. The Summer quiescent females $\left(0.19 \pm 0.08 \mathrm{ng} \mathrm{m}^{-1}\right)$ produced more $\mathrm{T}$ than the pregnant females $\left(0.40 \pm 0.22 \mathrm{ng} \mathrm{m}^{-1}\right)$ which received the same high GnRH dose (Fig. 3b).

In Autumn, mean plasma $\mathrm{T}$ concentrations were below $0.2 \mathrm{ng} \mathrm{ml}^{-1}$ at $\mathrm{t}_{0}$ in all treatment groups. The only group to show any response after $2 \mathrm{~h}$ to the GnRH injection was the high dose quiescent female treatment group: this group demonstrated a ten-fold increase in mean plasma $\mathrm{T}$ from $0.1 \pm 0.1 \mathrm{ng} \mathrm{ml}^{-1}$ to $1.2 \pm 0.4 \mathrm{ng} \mathrm{ml}^{-1}$ (Fig. 3c).

\section{Discussion}

\subsection{HPG axis activity in males}

The responsiveness of the HPG axis in male $T$. nigrolutea to external stimuli is characteristic of a temperate climate annually breeding animal synchronising its reproduction with the naturally changing seasons using external cues. Male reptiles commonly display an annual pattern of plasma $T$ with low concentrations during the early stages of spermatogenesis and a peak during spermiogenesis, corresponding with peak testicular hypertrophy (Lance, 1984).

Exogenous GnRH stimulated increases in plasma T concentrations in male T. nigrolutea in Spring when testes are hypertrophied and spermatogenesis is completed prior to mating (Edwards and Jones, 2001a). The roles of $\mathrm{T}$ in spermatogenesis (Lance, 1984), male aggression (Schuett et al., 1996) and male reproductive behaviour (Garstka et al., 1991) are well documented. We observed an increase in plasma $\mathrm{T}$ concentration which was proportional to the increasing $\mathrm{GnRH}$ doses although, due to high individual variation, the percentage increase only approached significance. This was because the response of some individuals in each GnRH treatment group (control, low, mid, high) was decreased plasma T concentrations, while the response of others was a clear increase. These contradictory responses are yet to be explained, but it is possible that there are two subclasses of males within the population which responded differently to the $\mathrm{GnRH}$ treatments. No dominance hierarchy within males of this species has been described, and there was no pattern linking dose and the nature of individual responses. High individual variation in hormone production following HPG axis stimulation has been reported in other reptiles (Licht and Porter, 1985; Lance and Vliet, 1987), while McGlothin et al. (2007) suggest that in the bird, Junco hyemalis, individual variation is linked to variation in mating effort.

As in Spring, the HPG axis in male T. nigrolutea was also responsive to exogenous $\mathrm{GnRH}$ in a dose-dependent manner in Summer, when males display regressed gonads and do not exhibit reproductive behaviours (Edwards and Jones, 2001a). It is possible that there are non-reproductive roles for $\mathrm{T}$ in male $T$. nigrolutea at this time of year, including somatic growth (Sutherland et al., 1995), as well as functions related to reproduction, such as the maintenance of gonads in a state of semireadiness to initiate spermatogenesis in Autumn, which might warrant maintenance of limited HPG axis responsiveness. Bhaktaraj et al. (2000) were able to induce changes in the testis and epididymis in a lizard during the non-breeding season using exogenous GnRH and T in combination. Shanbhag et al. (2000) demonstrated that while warm temperatures which would normally stimulate testicular activity have no effect during the post-breeding resting phase in a lizard, exogenous application of GnRH stimulated both testicular recrudescence and androgen production. It is possible then, that in male T. nigrolutea, higher brain centres become only partially thermorefractory during summer, leaving the HPG axis sensitive to stimulation at this time. Such thermorefractoriness would additionally negate the incurred energetic cost of constantly elevated plasma $\mathrm{T}$ concentrations (Sun et al., 2011), and may be akin to the post reproductive photorefractoriness which precedes molting and fattening in some birds (MacDougall-Shackleton et al., 2009).

Exogenous GnRH did not stimulate elevated plasma T concentrations in male T. nigrolutea in Autumn. This lack of response, even at the high GnRH dose, was not surprising, despite the fact that spermatogenesis is initiated in T. nigrolutea at this time (Edwards and Jones, 2001a): Plasma T concentrations are low in Autumn in this (Edwards and Jones, 2001a) and the related species Tiliqua rugosa (Bourne et al., 1986). In mammals the maintenance requirements for $\mathrm{T}$ in the final stages of spermatogenesis are lower than for its initiation (Handelman et al., 1999), but the reverse is generally true in reptiles (Lance, 1984). Complete refractoriness in response to $\mathrm{GnRH}$ challenge has been demonstrated in other vertebrates (Meddle et al., 2006; Millesi et al., 2002), although the level (s) at which this is enacted (hypothalamus, anterior pituitary or gonad) are unknown in T. nigrolutea.

While there was no significant E production in response to GnRH injection at any time of year in males, circulating basal $\left(t_{0}\right)$ concentrations of $\mathrm{E}$ did vary with reproductive stage, indicating some level of regulation. Concentrations were lowest during Summer (quiescence), and highest in Spring (final spermatogenesis), when they were comparable with the highest published plasma E2 concentrations in a male reptile, Podarcis sicula $\left(>1000 \mathrm{pg} \mathrm{ml}^{-1}\right.$ ) (Ando et al., 1992). It may be that there is no response to GnRH by way of $E$ production because the gonads are already responding maximally with respect to this steroid (Husak et al., 2009).

Circulating E concentrations in males are a function of several factors. In other male reptiles, the mitogenic effects of elevated $\mathrm{E}$ stimulated the initiation of spermatogenesis (Chieffi et al., 2002; Gist et al., 2007; Russo et al., 2005) or development of the reproductive tract (Gist et al., 2007). Alternatively, seasonal variation in aromatase activity may explain both the lack of an E response to $\mathrm{GnRH}$ and seasonal variation in plasma $\mathrm{E}$ concentrations (Gobbetti et al., 1994). In some reptiles, a decrease in plasma E has been linked with a post reproductive refractory period (Cardone et al., 1998; Gobbetti et al., 1994). In male T. nigrolutea, plasma E concentrations were lowest in Summer when males do not exhibit reproductive behaviours and testes are regressed (Edwards and Jones, 2001a); plasma E concentrations are highest in Spring, when spermiogenesis is completed. Furthermore, estrogens, as well as $\mathrm{T}$, are involved in the negative feedback control mechanisms of HPG axis function in males of some vertebrates (Callard et al., 1972; Tsai et al., 2005). Exposure to elevated circulating $\mathrm{E}$ may also be a regulatory mechanism by which seasonal breeders such as $T$. nigrolutea are able to time the onset of aspects of reproduction such as the initiation of spermatogenesis to coincide with favourable conditions for reproduction (Gobbetti et al., 1994). This suggests the possibility of a degree of regulation over HPG axis activity by E (directly, or indirectly via gonadotropin inhibiting hormone (GnIH) and or kisspeptins (Kriegsfeld, 2006; Tsutsui et al., 2010) and warrants further investigation. Few data are available on the effects of these newly discovered hypothalamic hormones in reptiles (Moussavi et al., 2013; Tsutsui et al., 2007), but it is likely that the mechanisms controlling the seasonal activation and deactivation of the HPG axis are under the influence of multiple hormones. 


\subsection{HPG axis activity in females}

Females of $T$. nigrolutea breed irregularly and must use external cues to synchronise reproduction to the natural seasons in breeding years but disassociate from these cues in non-breeding years. Female T. nigrolutea responded to the $\mathrm{GnRH}$ challenge with increased T, but not E, production, in both Summer and Autumn, when gonads were assumed to be quiescent. Previous studies demonstrated no elevation of $\mathrm{T}$ following $\mathrm{GnRH}$ injection in a bird (Hirschenhauser et al., 2000) and a mammal (Millesi et al., 2002) during reproductive quiescence. More recently, however, significant increased gonadal T production in response to $\mathrm{GnRH}$ during quiescence has been reported in a bird (DeVries et al., 2011). To our knowledge, this study is the first to demonstrate this response to exogenous GnRH stimulation in a nonbreeding year in a female reptile.

A response to HPG axis stimulation with $\mathrm{T}$ rather than $\mathrm{E}$ production is not unprecedented in female vertebrates. Elevated female $\mathrm{T}$ has been linked to vitellogenesis and ovulation in fish (Liley et al., 1986 cited in Whittier et al., 1987), reptiles (Edwards and Jones, 2001b; Taylor et al., 2004; Wibbels et al., 1992), and birds (Johnson 2000, cited in DeVries et al., 2011) and oviductal hypertrophy in lizards: oviducts bear receptors for $\mathrm{T}$ at particular times during the reproductive cycle (Girling, 2002).

Responsiveness to a hormone other than E may allow the uncoupling of vitellogenesis from other aspects of reproductive physiology or behaviour. Elevated T delays the onset of reproduction in female birds and reptiles (Ketterson et al., 2005): testosterone may act as a storage form of the steroid, as described in turtles (Rubenstein and Wikelski, 2005), to avoid untimely recruitment of new follicles in an antigestrogenic capacity similar to that of progesterone (Callard et al., 1992). Production of T instead of $\mathrm{E}$ in response to $\mathrm{GnRH}$ prior to hibernation may be the mechanism by which initiation of the next reproductive effort is delayed until a more appropriate time of year, or until some threshold level of body condition is reached. Aspic vipers (Vipera aspis) display a clear threshold of body condition, below which females do not breed: plasma estradiol concentrations are significantly higher in individuals of greater body condition (Aubret et al., 2002). In light of data from the present study, links between body condition and reproductive frequency in female $T$. nigrolutea are an avenue for future investigation.

The high dose animals classified as quiescent in Summer (December) showed an increase in $\mathrm{T}$ production in response to $\mathrm{GnRH}$, indicating their HPG axis was able to respond to stimulation during a period of gonadal quiescence (Edwards et al., 2002b). It is tempting to speculate that this sensitivity is related to preparation for the next reproductive effort, which is, at that time, approximately 910 months in the future. Further, quiescent females which received the high GnRH dose responded similarly in Autumn, now only 67 months from their next reproductive effort. Vertebrate species sensitive to photoperiodic cues can anticipate forthcoming seasons (Revel et al., 2007), and Jones and Swain (2000) demonstrated that a female lizard determines litter size in early vitellogenesis, perhaps by assessing their own body condition. More recent research indicates that interactions between GnRH, kisspeptins and melatonin may assist females in assessing their body condition whilst making "decisions" about reproductive frequency (Revel et al., 2007). The actions of metabolic hormones such as thyroxine, corticosterone and leptin also warrant further investigation as mechanisms by which the female reproductive system could be receiving signals on which to base future reproductive decisions.

\section{Conclusions}

Our results suggest that patterns of reproductive axis responsiveness to exogenous GnRH stimulation vary with sex, season and reproductive condition. Males displayed highest circulating $\mathrm{T}$ concentrations in Spring, coincident with final spermatogenesis and mating, but showed the greatest increase in response to $\mathrm{GnRH}$ in Summer, during gonadal quiescence, and, surprisingly, did not elevate circulating E concentrations at any time of year. Stimulation of $\mathrm{T}$ and $\mathrm{E}$ production is likely to have occurred via activation of the full HPG axis, although it is not possible to exclude the possibility of a direct action of GnRH on the gonads (Shanbhag et al., 2000). All induced peak hormone concentrations in response to $\mathrm{GnRH}$ injection were within expected physiological ranges (Edwards and Jones, 2001a,b), confirming that the high dose GnRH used for this study was the most appropriate to assess HPG responsiveness without resulting in supraphysiological stimulation. Female $T$. nigrolutea displayed responses more complicated than simply switching on and off a reproductive response. Reproductive and quiescent females did not demonstrate different $\mathrm{E}$ responses to GnRH. However, quiescent females, presumably preparing to reproduce in the subsequent active season, demonstrated an increase in T production. Data collected from males indicate that our methodology was appropriate, but sample sizes were small, and conclusions can only be drawn cautiously. This study opens the way for further investigation into the mechanisms by which internal (body condition) and external seasonal cues (temperature and photoperiod) are coordinated to regulate reproduction in irregularly-breeding reptiles.

\section{Acknowledgments}

Work was conducted under University of Tasmania animal ethics approval number A0008141. Funding support for this work was provided by a University of Tasmania Internal Research Grant Scheme funding to A.E. Thanks go to A/Prof. Leon Barmuta and A/Prof. Erik Wapstra for statistical advice, and to A/Prof. Brett Gartrell and two anonymous reviewers for comments on the manuscript.

\section{References}

Ando, S., Ciarcia, G., Panno, M.L., Imbrogno, E., Tarantino, G., Buffone, M., Beraldi, E., Angelini, F., Botte, V., 1992. Sex steroids in the plasma and testis during the reproductive cycle of the lizard Podarcis s. sicula Raf. Gen. Comp. Endocrinol. 85, 1-7.

Aubret, F., Bonnet, X., Shine, R., Lourdais, O., 2002. Fat is sexy for females but not for males: the influence of body reserves on reproduction in snakes (Vipera aspis). Horm. Behav. 42, 135-147.

Bhaktaraj, B., Patil, S., Patil, S.B., 2000. GnRH and/or testosterone induced changes in reproductive activities during nonbreeding season in Calotes versicolor (Daud.) Indian J. Exp. Biol. 38, 873-876.

Bonnet, X., Naulleau, G., Mauget, R., 1994. The influence of body condition on 17- $\beta$ estradiol levels in relation to vitellogenesis in female Vipera aspis (Reptilia, Viperidae). Gen. Comp. Endocrinol. 93, 424-437.

Bourne, A.R., Taylor, J.L., Watson, T.G., 1986. Annual cycles of plasma and testicular androgens in the lizard Tiliqua (Trachydosaurus) rugosa. Gen. Comp. Endocrinol. 61, 278-286.

Callard, I.P., Chan, S.W.C., Potts, M.A., 1972. The control of the reptilian gonad. Am. Zool. 12, 273-287.

Callard, I.P., Fileti, L.A., Perez, L.E., Sorbera, L.A., Giannoukos, G., Klosterman, L.K., Tsang, P., McCracken, J.A., 1992. Role of the corpus luteum and progesterone in the evolution of vertebrate viviparity. Am. Zool. 32, 264-275.

Cardone, F., Angelini, B., Varriale, B., 1998. Autoregulation of estrogen and androgen receptor mRNA and downregulation of androgen receptor mRNA by estrogen in primary cultures of lizard testis cells. Gen. Comp. Endocrinol. 110, 227-236.

Chieffi, P., Colucci D'Amato, L., Guarino, F., Salvatore, G., Angelini, F., 2002. 17 $\beta$ Estradiol induces spermatogonial proliferation through mitogen-activated protein kinase (extracellular signal-regulated kinase 1/2) activity in the lizard (Podarcis sicula). Mol. Reprod. Dev. 61, 218-225.

DeVries, M.S., Winters, C.P., Jawor, J.M., 2011. Testosterone elevation and response to gonadotropin-releasing hormone challenge by male Northern Cardinals (Cardinalis cardinalis) following aggressive behaviour. Horm. Behav, 62, 99-105.

Edwards, A., Jones, S.M., 2001a. Changes in plasma testosterone, estrogen and progesterone concentrations throughout the annual reproductive cycle in male viviparous blue-tongued skinks, Tiliqua nigrolutea, (Scincidae), in Tasmania. J. Herpetol. 35, 293-299.

Edwards, A., Jones, S.M., 2001b. Changes in plasma progesterone, estrogen and testosterone concentrations throughout the reproductive cycle in female 
viviparous blue-tongued skinks, Tiliqua nigrolutea, (Scincidae), in Tasmania. Gen. Comp. Endocrinol. 122, 260-269.

Edwards, A., Jones, S.M., Wapstra, E., 2002a. Multiennial reproduction in females of a viviparous, temperate-zone skink, Tiliqua nigrolutea. Herpetologica 58, 407414.

Edwards, A., Jones, S.M., Davies, N.W., 2002b. A possible alternative to 17 $\beta$-estradiol in a viviparous lizard, Tiliqua nigrolutea. Gen. Comp. Endocrinol. 129, 114-121.

Garstka, W.R., Cooper Jr., W.E., Wasmund, K.W., Lovich, J.E., 1991. Male sex steroids and hormonal control of male courtship behaviour in the yellow-bellied slider turtle, Trachemys scripta. Comp. Biochem. Physiol. A 98, 271-280.

Gartrell, B.D., Girling, J.E., Edwards, A., Jones, S.M., 2002. Comparison of noninvasive methods for the evaluation of female reproductive condition in a large viviparous lizard, Tiliqua nigrolutea. Zoo Biol. 21, 253-268.

Girling, J.E., 2002. The reptilian oviduct: a review of structure and function and directions for future research. J. Exp. Zool. 293, 141-170.

Gist, D.H., Bradshaw, S., Morrow, C.M.K., Congdon, J.D., Hess, R.A., 2007. Estrogen response system in the reproductive tract of the male turtle: an immunocytochemical study. Gen. Comp. Endocrinol. 151, 27-33.

Gobbetti, A., Zerani, M., Di Fiore, M.M., Botte, V., 1994. Relationships among GnRH, substance P, prostaglandins, sex steroids and aromatase activity in the brain of the male lizard Podarcis sicula sicula during reproduction. J. Reprod. Fertil. 101, $523-529$.

Handelman, D.J., Spaliviero, J.A., Simpson, J.M., Allan, C.M., Singh, J., 1999. Spermatogenesis without gonadotropins: maintenance has a lower testosterone threshold than initiation. Endocrinology 140, 3938-3946.

Heatwole, H., Taylor, J., 1987. Reproductive ecology. In: Heatwole, H. (Ed.), Ecology of Reptiles. Surrey Beatty and Sons Pty Ltd, N.S.W., Australia, pp. 147-166.

Hirschenhauser, K., Möstl, E., Péczely, P., Wallner, B., Dittami, J., Kotrschal, K., 2000. Seasonal relationships between plasma and fecal testosterone in response to GnRH in domestic ganders. Gen. Comp. Endocrinol. 118, 262-272.

Hseuh, A.J.W., Jones, P.B.C., 1981. Extrapituitary actions of gonadotropin-releasing hormone. Endocrinol. Rev. 2, 437-461.

Husak, J.F., Irschick, D.J., Henningsen, J.P., Kirkbride, K.S., Lailvaux, S.P., Moore, I.T., 2009. Hormonal response of male green anole lizards (Anolis carolinensis) to GnRH challenge. J. Exp. Zool. A 309, 1-10.

Jawor, J.M., McGlothlin, J.W., Casto, J.M., Grieves, T.I., Snajdr, E.A., Bentley, G.E., Ketterson, E.D., 2006. Seasonal and individual variation in response to GnRH challenge in male dark-eyed juncos (Junco hyemalis). Gen. Comp. Endocrinol. $149,182-189$.

Jones, S.M., 2011. Hormonal regulation of ovarian function in reptiles. In: Norris, D. O., Lopez, K.H. (Eds.), Reptiles, vol. 3. Elsevier, San Diego, pp. 89-113.

Jones, S.M., Swain, R., 2000. Effects of exogenous FSH on follicular recruitment in a viviparous lizard Niveoscincus metallicus. Comp. Biochem. Physiol. A 127, 487493.

Ketterson, E.D., Nolan Jr., V., Sandell, M., 2005. Testosterone in females: mediator of adaptive traits, constraint on sexual dimorphism, or both? Am. Nat. 166, 85-98.

Kriegsfeld, L.J., 2006. Driving reproduction: RFamide peptides behind the wheel. Horm. Behav. 50, 655-666.

Kriegsfeld, L.J., Nelson, R.J., 1999. Photoperiod affects the gonadotropin-releasing hormone neuronal system of male prarie voles (Microtus ochrogaster). Neuroendocrinology 69, 238-244.

Kumar, S., Roy, B., Rai, U., 2011. Hormonal regulation of testicular function in reptiles. In: Norris, D.O., Lopez, K.H. (Eds.), Reptiles, vol. 3. Elsevier, San Diego, pp. 63-88.

Lance, V., 1984. Endocrinology of reproduction in male reptiles. Symp. Zool. Soc. Lond. 52, 357-383.

Lance, V.A., Vliet, K.A., 1987. Effects of mammalian gonadotropins on testosterone secretion in male alligators. J. Exp. Zool. 241, 91-94.

Licht, P., Porter, D.A., 1985. LH secretion in response to gonadotropin releasing hormone (GnRH) by superfused pituitaries from two species of turtles. Gen. Comp. Endocrinol. 59, 442-448.

Lovern, M.B., 2011. Hormones and reproductive cycles. In: Norris, D.O., Lopez, K.H. (Eds.), Reptiles, vol. 3. Elsevier, San Diego, pp. 321-353.

MacDougall-Shackleton, S.A., Stevenson, T.J., Watts, H.E., Pereyra, M.E., Hahn, T.P., 2009. The evolution of photoperiod response systems and seasonal GnRH plasticity in birds. Intergr. Comp. Biol. 49, 580-589.
McGlothin, J.W., Jawor, J.M., Ketterson, E.D., 2007. Natural variation in a testosterone-mediated trade-off between mating effort and parental effort. Am. Nat. 170, 864-875.

Meddle, S.L., Wingfield, J.C., Millar, R.P., Deviche, P.J., 2006. Hypothalamic GnRH-1 and its precursor during photorefractoriness onset in free-living male darkeyed juncos (Junco hyemalis) of different year classes. Gen. Comp. Endocrinol. $145,148-156$.

Millesi, E., Hoffmann, I.E., Steurer, S., Metwaly, M., Dittami, J.P., 2002. Vernal changes in the behavioural and endocrine responses to GnRH application in male European ground squirrels. Horm. Behav. 41, 51-58.

Moussavi, M., Wlasichuk, M., Chang, J.P., Habibi, H.R., 2013. Seasonal effect of gonadotrophin inhibitory hormone on gonadotropin-releasing hormoneinduced gonadotroph functions in the goldfish pituitary. J. Neuroendocrinol. 25, 506-516.

Revel, F.G., Ansel, L., Klosen, P., Saboureau, M., Pévet, P., Mikkelsen, J.D. Simonneaux, V., 2007. Kisspeptin: a key link to seasonal breeding. Rev. Endocr. Metab. Disord. 8, 57-65.

Rubenstein, D.R., Wikelski, M., 2005. Steroid hormones and aggression in female Galápagos marine iguanas. Horm. Behav. 48, 329-341.

Russo, M., Troncone, G., Guarino, F.M., Angelini, F., Chieffi, P., 2005. Estrogeninduced Akt-1 activity in the lizard (Podarcis s. sicula) testis. Mol. Reprod. Dev. 71, 52-57.

Schuett, G.W., Harlow, H.J., Rose, J.D., Van Kirk, E.A., Murdoch, W.J., 1996. Levels of plasma corticosterone and testosterone in male copperheads (Agkistrodon contortix) following staged fights. Horm. Behav. 30, 60-68.

Shanbhag, B.A., Radder, R.S., Saidapur, S.K., 2000. GnRH but not warm temperature induces recrudescence of quiescent testes in the tropical lizard Calotes versicolor (Daud.) during postbreeding phase. Gen. Comp. Endocrinol. 119, 232-238.

Shine, R., Olsson, M., 2003. When to be born? Prolonged pregnancy or incubation enhances locomotor performance in neonatal lizards (Scincidae). J. Evol. Ecol. $16,823-832$.

Somoza, G.M., Miranda, L.A., Strobl-Mazzulla, P., Gastón Guilgur, L., 2002. Gonadotropin-releasing hormone $(\mathrm{GnRH})$ : from fish to mammalian brains. Cell. Mol. Neurobiol. 22, 589-609.

Sun, B.-J., Du, W.-G., Suh, L., Chen, Y., Wang, Y., 2011. The influence of thermal environment and food availability on testosterone and gonadal recrudescence in male Chinese skinks [Plestiodon (Eumeces) chinensis]. Gen. Comp. Endocrinol. $170,449-454$.

Sutherland, R.L., Hamilton, J.A., Sweeney, K.J.E., Watts, C.K.W., Musgrove, E.A., 1995 Steroidal regulation of cell cycle progression. In: Bock, G.R., Goode, J.A. (Eds.) Non-reproductive Actions of Sex Steroids. John Wiley and Sons Ltd, England, pp. $218-234$.

Taylor, E.N., DeNardo, D.F., Jennings, D.H., 2004. Seasonal steroid hormone levels and their relation to reproduction in the Western Diamond-backed Rattlesnake, Crotalus atrox (Serpentes: Viperidae). Gen. Comp. Endocrinol. 136, 328-337.

Tsai, P.-S., Kessler, A.E., Jones, J.T., Wahr, K.B., 2005. Alteration of the hypothalamicpituitary-gonadal axis in estrogen- and androgen-treated adult male leopard from, Rana pipiens. Reprod. Biol. Endocrinol. 3, 2. http://dx.doi.org/10.1186/ 1477-7827-3-2.

Tsutsui, K., Bentley, G.E., Ubuka, T., Saigoh, E., Yin, H., Osugi, T., Inoue, K., Chowdhury, V.S., Ukena, K., Ciccone, N., Sharp, P.J., Wingfield, J.C., 2007. The general and comparative biology of gonadotropin-inhibitory hormone $(\mathrm{GnIH})$. Gen. Comp. Endocrinol. 153 (2007), 365-370.

Tsutsui, K., Bentley, G.E., Bedecarrats, G., Osugi, T., Ubuka, T., Kriefsfeld, L.J., 2010 Gonadotropin-inhibitory hormone $(\mathrm{GnIH})$ and its control of central and peripheral reproductive function. Front. Neuroendocrinol. 31, 284-295.

Whittier, J.M., Mason, R.T., Crews, D., 1987. Plasma steroid hormone levels of female red-sided garter snakes, Thamnophis sirtalis parietalis: relationship to mating and gestation. Gen. Comp. Endocrinol. 67, 33-43.

Wibbels, T., Owens, D.W., Licht, P., Limpus, C.J., Reed, P.C., Amoss Jr., M.S., 1992 Serum gonadotropins and gonadal steroids associated with ovulation and egg production in sea turtles. Gen. Comp. Endocrinol. 87, 71-78. 